\title{
A matéria histórica interroga a forma mítica
}

Danielle Corpas ${ }^{1}$

PACHECO, Ana Paula. Lugar do mito: narrativa e processo social nas Primeiras estórias de Guimarães Rosa.

São Paulo: Nankin, 2006

Num artigo publicado em 2001, Ana Paula Pacheco assinalou o seguinte problema na recepção de Guimarães Rosa: “o perigo da regressão mítica de cunho conservador ronda a obra rosiana cada vez que nela a representação do atraso não parece a alguns viga de nossa modernização, e sim remanescente arcaico, mito nacionalista a frisar positivamente o que é defasagem" ". Esse perigo, ela contornou muito bem em Lugar do mito: narrativa e processo social nas Primeiras estórias de Guimarães Rosa. Em perspectiva rigorosamente materialista, o exercício crítico aí passa ao largo de qualquer tipo de apologia idealista da amplitude simbólica ou alegórica das narrativas, do elogio inócuo à habilidade do escritor em incorporar ao seu mundo-sertão signos de ressonância metafísica ou mitológica. Pelo contrário, a dimensão mítica é percebida como componente de um problema formal no qual se cristalizam impasses da história. O trabalho põe em discussão os "dilemas da representação" presentes em cada narrativa e na arquitetura de Primeiras estórias (1962), onde se imbricam a propensão rosiana para o transcendente e as contradições da modernização conservadora à brasileira. Refletir sobre o tratamento mítico da história do país na composição literária é um desafio que vem sendo encarado por uma leva de bons escritos sobre Rosa desde meados da década de 1990. Essa recepção está redimensionando a importância de sua prosa, tirando-a da posição de "grande obra" celebrada incondicionalmente para valorizá-la como feito estético capaz de se haver com a representação de problemas

1 Professora visitante no Departamento de Ciência da Literatura da Faculdade de Letras da Universidade Federal do Rio de Janeiro.

2 PACHECO, Ana Paula. História, psique e metalinguagem em Guimarães Rosa. Cult Revista brasileira de literatura, São Paulo, ano IV, n. 43, p. 42-47, 2001. 
pungentes da experiência brasileira. Talvez esse movimento no tabuleiro crítico seja mais perceptível quando se trata do divisor de águas que é Grande sertão: veredas - em meio a tantas leituras em disputa sobre a obra-prima, aquelas cujo foco mantém um olho na forma singular do romance e outro no histórico da formação do Brasil moderno vêm conquistando mais espaço na pauta dos debates. Lugar do mito cobre uma lacuna nessa fortuna crítica recente, até então desprovida de uma reflexão abrangente que lançasse luz sobre a vinculação e a tensão entre mito e matéria histórica no livro publicado em 1962.

\section{Molduras, tonalidades e pontos de vista}

Postos lado a lado em Lugar do mito, os dois extremos de Primeiras estórias ("As margens da alegria" e "Os cimos") delineiam a moldura temporal que situa o volume: a arrancada modernizadora ocorrida no governo de Juscelino Kubitschek - esse é o ponto de partida do estudo. Afora outros índices de modernização disseminados nesses e nos demais contos, a construção de Brasília, ícone do período, é referência evidente nas duas narrativas protagonizadas pelo Menino. O livro de Rosa nos lança, portanto, num período de transformação da paisagem de roças e campos contemplada do alto em "As margens da alegria". Período em que o capitalismo brasileiro acelera seu ajustamento à sofisticação da lógica industrial (inclusive na produção rural) e ao sistema financeiro mundial; período em que se intensifica o convívio tenso entre modos de viver e de pensar arraigados no passado escravocrata (patriarcalista, mandonista, elitista) e os novos parâmetros da civilidade urbana (nominalmente esclarecida, institucional, democrática).

Na medida em que avança a explanação, vamos percebendo como esse ritmo de mudanças alimentou os "dilemas da representação" com os quais se defrontou Guimarães Rosa. O mítico vai aparecendo como "modo da cultura popular redimensionado pelo olhar erudito" (p. 18) e influência na figuração de "dinâmicas da identidade pessoal e coletiva" (p. 20). Assinaladas logo de saída, essa condição e essa função já indicam que relações entre estratos culturais e sociais, conformação de subjetividade e organização da sociedade serão aspectos privilegiados na abordagem das diferentes maneiras como mito e história se entretecem - as tonalidades que assumem as narrativas. De fato, a incorporação do traço mitificador nessa ficção é observada o tempo todo pelo prisma da armação do ponto de vista que comanda as narrativas e a simbolização da experiência social; é permanente a atenção à configuração do foco narrativo, ao lugar social dos narradores, à distância e/ou proximidade que mantém em relação à mentalidade 
sertaneja. Atenta também ao "olhar de classe do escritor" e aos "limites da grande obra", Ana Paula indica como e onde as estórias alcançam "a superação literária de seus impasses, ao formalizar contradições que são da matéria, do país" (p. 218, grifos da autora). É por essa via que o trabalho vai nos esclarecendo o que está por trás da assimilação ou da denegação da dimensão mítica, a que responde, no contexto da modernização acelerada, o diálogo com uma ótica não moderna, quais impasses históricos estão implicados nas opções formais que lidam com o pensamento amparado no mito.

Entendido inicialmente como (tentativa de) contraponto à realidade objetiva, material, das personagens via de regra excluídas, o mítico surge na dobradiça do foco narrativo ora como mentira, ora como sabedoria, mas também como mentira (que é) histórica, ou seja, visada do mundo que revela, no seu modo de entender/suprimir a História, contradições sociais verdadeiras. O mítico como resposta a mudanças, como leitura do processo social, como resguardo de uma cultura; enfim, como atraso e simultaneamente como resposta a um "progresso" desigual. [p. 19, grifos da autora]

Antes de chegar a esses resultados, vale atentar para uma segunda moldura de que a crítica lança mão. Ao contrário da primeira (a baliza histórica anunciada de saída), essa outra vai se configurando pouco a pouco, sem alarde, conforme a demanda da discussão em curso, de modo menos programático que ensaístico. Vou chamá-la, na falta de termo melhor, de moldura literária.

Muitas vezes, a argumentação progride por meio de comparações entre Primeiras estórias e obras anteriores de Guimarães Rosa, de outros autores brasileiros (Machado de Assis, Graciliano Ramos) ou do cânone ocidental (de Édipo-Rei a Edgard Allan Poe e Pirandello). No caso da literatura estrangeira, as referências apóiam a análise em andamento - é o que ocorre no capítulo sobre "O espelho" com o rol de narrativas européias e norte-americanas centradas no tema do duplo. Já a tradição literária local parece ser evocada para definir com mais precisão um diferencial entre a representação da história nas estórias e em prosas que respondem a outras circunstâncias - de modo que essa segunda moldura, mais tênue, reforça a primeira, ao sinalizar o lugar do livro de 1962 no conjunto da produção rosiana e no sistema literário nacional. Se no irônico espelho machadiano se vê “o burguês perfeitamente invulnerável” diante da possibilidade de questionamento à "lei cínica da sociabilidade liberal-escravocrata" (p. 251-252), no conto de Guimarães Rosa a especulação resulta, conforme mostra a 
leitura de Ana Paula, na visão de uma sociedade moderna, porém "sem formas estáveis de constituição do sujeito [autônomo], como de si mesma, [...] que refrata em mônadas de crenças individuais imagens de sua anomia social” (p. 255). O contraste entre estágios da formação nacional - e entre as respostas estéticas que lhes são correspondentes - também fica bastante evidente quando a análise se desvia de seu objeto central para comentar "A hora e vez de Augusto Matraga" ou Grande sertão: veredas. São passagens que exprimem bem como, nos modos específicos com que se efetua a notação da história na mimese, pode-se observar o ritmo do processo social. Um exemplo:

A violência dos jagunços [em Grande sertão: veredas] - ali isolada de outras violências sociais - podia ser imaginada como forma de redenção, talvez uma aposta na desordem ordenadora à margem da vida política que se estabelecia, desde épocas remotas, entre governo e coronéis, donos do país. Nesse sentido, é curioso pensar que o regionalismo (romântico e sobretudo em sua fase "realista", isto é, de escola realista) antepunha o homem civilizado ao caipira, como se aquele fosse reformar o Brasil "bárbaro". Já Guimarães Rosa, nesse livro da década de 50 - mas cujas ações se passam durante a Primeira República -, encena simbolicamente o contrário, talvez numa linha de continuidade modernista, apostando num substrato "primitivo" (e mítico) do país. [p. 106-107]

A aposta no mítico - viável no espaço e no tempo em que transitam Riobaldo e Augusto Matraga, uma vez que a dimensão do sagrado ali funcionava de fato como princípio organizador da vida social ${ }^{5}$ - ganha nuanças distintas em Primeiras estórias. Os três primeiros capítulos de Lugar do mito abordam separadamente três tonalidades da imbricação entre mito e história no volume: o aventuresco, o anedótico e o trágico. Notando, em cada grupo de contos, a presença mais ou menos intensa de veios míticos e o alcance de sua eficácia como solução formal em relação à matéria da narrativa, a crítica vai especificando os sentidos do procedimento mitificante. Vamos a eles.

No primeiro grupamento de contos (aqueles em que o narrador adere ao imaginário infantil), a resposta ao ritmo da modernização deixa entrever

3 Neste passo, Ana Paula não deixa de assinalar que em Grande sertão: veredas a eficácia do mito já se vê relativizada, que a fala do jagunço letrado "já deixa entrever os limites da explicação mítica do mundo" ao preocupar-se com uma potência de destruição puramente humana, e desvinculada da racionalidade e da idéia de justiça (p. 105). 
um tom de descontentamento. Seguindo a via do lúdico ("Partida do audaz navegante", "Pirlimpsiquice", "Os cimos"), do mágico-religioso ("A menina de lá”), da rememoração ("Nenhum, nenhuma”) ou do resgate de integração com a natureza ("As margens da alegria”), os enredos se estruturam pela complementaridade de dois movimentos: descoberta do mundo desencantado e anseio de reencantamento. É grande aí o investimento na fabulação mitificadora, que promove a redução do percurso histórico à abstração de encenações da existência, com o fito de recuperar uma harmonia nostálgica, pré-moderna. No espaço privado em que circulam as crianças protagonistas, o idealismo rosiano se desdobra em poética do desejo - "experiência de perdas efetivas, recriar um mundo mais satisfatório, em que carências e sofrimentos teriam compensações simbólicas" (p. 44) - e em poética essencializante -"reaver, na redução do percurso histórico, o coração da existência", "uma 'substância' guardada na infância distante" e perdida na azáfama do mundo adulto, na conturbação da esfera pública (p. 29, grifos da autora). No refúgio do universo infantil pode-se - pelo passe de mágica do "era uma vez" mítico-aventuresco, que engendra cosmogonias, contos maravilhosos ou epopéias (subjetivas, por modernas) - figurar um mundo belo e ideal, reversão estética da realidade opressora, recriação simbólica que liberta das contingências do momento histórico, restando estas apenas como pálido pano de fundo. Com relação a essas estórias comoventes, o juízo crítico ressalta que são, no volume, as que manifestam com mais intensidade o escapismo da faceta idealizante presente na criação de Guimarães Rosa o "lado menos atual" de sua obra (p. 47). Por outro lado, vantagem da "poética feita de contradições" (p. 18) em boa parte responsável pelo valor do livro, algumas narrativas não deixam de apontar para a limitação do idealismo - por exemplo, no salto para o vazio que dá o narrador de "Pirlimpsiquice", encerrando o transe em que se converteu a apresentação teatral, fazendo frente à dissolução da individualidade, à substituição do mundo pela representação essencializante que abole a materialidade da experiência histórica. Em outras palavras: nas encenações da existência que convocam o mítico-aventuresco como alternativa à reificação da vida no contexto moderno, a dimensão mítica parece pretender substituir a história. Porém, com a insistência própria dos dados de realidade, esta retorna pelas frestas da forma mitificadora, como se vê em "Nenhum, nenhuma" - aí a fabulação encantatória forjada na subjetividade se vê diante dos limites que o mundo lhe impõe, sua aspiração totalizadora esbarra na contingência de um tempo no qual já se perdeu a coesão coletiva que conferia eficácia ao mito. Essa estratégia de representação enfrenta, então, a crise - impossibilidade tanto de submeter o mundo a suas pretensões ordenadoras quanto de contorná-lo definitivamente no refúgio imaginário. 
A falibilidade da associação entre mito e conjuntura moderna fica mais evidente no segundo conjunto de contos, aqueles que compartilham o tom anedótico. O mito comparece, nesse caso, em versão negativa: um ciclo de violência e uma maldição familiar que não se cumprem ("Os irmãos Dagobé"); a paródia de aventura romanesca em "Tarantão, meu patrão", espécie de périplo épico satirizado; a astúcia homérica com as palavras ("Famigerado", "Fatalidade"), fundamento mítico que vinca a atitude esclarecida, como mostram Adorno e Horkheimer em sua Dialética do esclarecimento. São enredos, ambientados na esfera pública, que tematizam a violência sem recorrer ao mítico-mágico, deixando a matéria histórica mais visível. Uma revelação desencantada de matizes da dinâmica política que põe em cena meandros de um processo em curso no contexto do desenvolvimentismo J. K.: o trânsito (incompleto, como sabemos) do convívio regrado pela violência privada para a ordenação civil, garantida (ao menos nominalmente) pelas instituições do poder público. Aqui também a percepção do fluxo para a modernidade tem a marca da contrariedade. Apresentando o novo quadro das relações de poder no sertão, reflexo da crescente hegemonia urbana, os contos fazem graça com as promessas do progresso, que não alcança resolver problemas seculares de nossa sociabilidade sobreposição de poder público e força privada, reversibilidade entre ordem e desordem, cordialidade misturada a institucionalidade. É emblemática, nesse sentido, a atitude do delegado culto de "Fatalidade", que conduz o sertanejo pacífico em busca de garantia legal a fazer justiça com as próprias mãos.

Nesse anedotário, nota-se o recuo da mitificação, tornada derrisória. O que avulta é o procedimento chistoso. Ao destacá-lo, a crítica chama atenção para o sentido do equilíbrio entre dimensão mítica (residual) e tratamento humorístico das questões da esfera política. Justo quando vem à superfície um aspecto distintivo (e grave) da matéria histórica - "tensão gerada pela passagem, incompleta, entre mando pessoal e lei” (p. 113) - a representação convida ao riso. Riso discreto - é sempre discreta a comicidade em Guimarães Rosa -, e a análise não deixa de reconhecer nessa discrição algo do "caráter específico da nossa sociabilidade" (p. 113). Pois trata-se de um riso entre pares (narrador e leitor esclarecidos), que provém da quebra das expectativas de encaminhamento do enredo alimentadas pelo confronto entre vigência da tradição política arcaica nas comunidades que participam da ação e intervenção de recursos civilizatórios recém-instaurados. Nem o ciclo da violência mítica nem a civilidade se efetivam. $\mathrm{O}$ desfecho é risível - da perspectiva de classes que têm o privilégio de manipular a ambigüidade da situação - pelo realce de um descompasso no trânsito para a legalidade. 
O humor, neste conjunto, não é o riso que permaneceu fora da mentira oficial, como o da cultura popular, presente no livro na praça pública da cidade, como se vê em "Darandina". Mas traz seu crivo crítico, não na superioridade de quem o manipula, e sim na composição que dá a ver o procedimento. Entre a lei e o mando, a anedota, como vimos, parece rir dessa nossa incapacidade histórica de nos “civilizarmos". [p. 114]

Como esse, outros impasses históricos da modernização à brasileira encontram-se formalizados com mais radicalidade nos contos em que o veio mítico se reveste de tonalidade trágica - "nos quais uma consciência em trânsito, entre o arbítrio e a necessidade, entre razões míticas e ordem citadina, permeia situações de catástrofe" (p. 20). O trágico aí é tomado em seu sentido rigoroso, bem estabelecido pelo paralelismo entre o quadro histórico da tragédia ática e o contexto brasileiro, em que o arcaico é constitutivo do moderno: "certa dimensão de encantamento permanece, contraface de um país em que o capitalismo se manteve conjugado a uma ordem pré-burguesa no que se refere ao tratamento da pessoa, à sua constituição como sujeito de direitos" (p. 121).

No conjunto formado por "A benfazeja", "A terceira margem do rio", "Substância", "Sorôco, sua mãe, sua filha" e "Nada e a nossa condição", cruzam-se posse e privação, perspectiva mítico-religiosa e instrumental esclarecido, mundo do trabalho e transcendência, discurso individual e imaginário coletivo, pontos de vista de classes distintas. À diferença da atmosfera de sonho (ou pesadelo), da graça delicada ou pungente que perpassa os contos focados em crianças, nesses outros sobressai a concretude vívida dos percalços: o sofrimento deixa marcas nos corpos de várias personagens, a ação deixa à mostra condições de vida muito precárias (ausência de recursos institucionais, trabalho degradante, exclusão social, desespero). A notação mitificadora da história tem mais densidade - mais peso crítico - sobretudo quando ocorre paralisação do mito ("A benfazeja”, "A terceira margem do rio", "Nada e a nossa condição"), quando a forma literária, lidando com experiências-limite sem amainar sua gravidade, põe em xeque a possibilidade de simbolizar saídas para contradições históricas bem precisas, que o não-tempo mítico pretende transcender. Sobretudo nas narrativas em que há mescla de vozes sociais, em que a mitificação viceja no cruzamento entre lógica coletiva de comunidade pobre e estratégia persuasiva de narrador esclarecido - "A benfazeja", "Nada e a nossa condição" -, o mito surge como construção fissurada. Já não mais repositório de convicções inabaláveis, como no pensamento religioso, a ordem mítica participa de uma postulação, funciona como artifício que confere (falsa) universalidade 
ao plaidoyer apaziguador de uma voz em primeira pessoa. O momento de verdade do mito coletivo se estilhaça no choque com a matéria histórica, na qual a distância entre classes e o insulamento da subjetividade, minando por entre as fissuras da tentativa de reversão simbólica da realidade problemática, põe sob suspeita a própria solução mítica.

O juízo sobre o recurso à mitificação como estratégia persuasiva de narrador em primeira pessoa é um dos mais altos rendimentos críticos de Lugar do mito, contribuição importante para o entendimento da obra de Guimarães Rosa (vale lembrar que também o narrador de Grande sertão: veredas está às voltas com um trabalho de persuasão que envolve a dimensão mítica). Agenciado pela perspectiva esclarecida, o espectro mítico, sob as lentes críticas de Ana Paula Pacheco, dá a ver os contornos da naturalização do destino histórico em nossa modernidade excludente, sem margem para a alteridade, suspensa na má infinitude da passagem para a civilidade prometida. 